\title{
MANHOOD AND THE OTHER: SEXUALITY AND SOCIABILITY IN STEPHEN KING'S FICTION
}

A MASCULINIDADE E O OUTRO: SEXUALIDADE E SOCIABILIDADE NA FICÇÃO DE STEPHEN KING

Diego Moraes Malachias Silva Santos*
* diegomalachias@gmail.com

Bachelor of Letters in Literatures in English (UFMG), MA in Literary Studies (UFMG), PhD in Literary Studies in progress (UFMG). Research supported by MA and PhD scholarships from the CAPES. This article is a revised version of the third chapter from my MA thesis, Masculinity as an Open Wound in Stephen King's Fiction.

ABSTRACT: This article examines the relation between traditional masculinity, femininities, and untraditional masculinities in Stephen King's novels, exploring the influence manhood and social relations have on each other. Section one, which deals with male/male social and sexual interactions, explores sexuality as an indicator of morality in King's fiction, homophobia as a possible mask for repressed homosexuality, and male homosociality being defined via ostracism. Section two centers on male/female relationships. Through a myriad of devices, King's male characters exclude the feminine to reassert an allegedly emasculated manhood. Often, however, their assessment reveals more about the frailty of traditional masculinity than it exposes truly patronizing women. Gendered social interactions in King's works reveal unstable masculinities that seem beyond hope, as male characters refuse to acknowledge their problems.

KEYWORDS: masculinity; Stephen King; sexuality. textos de King, masculinidades instáveis e aparentemente destituídas da esperança de quaisquer melhoras, já que personagens masculinos se recusam a reconhecer seus problemas.

PALAVRAS-CHAVE: masculinidade; Stephen King; sexualidade. 
In the anxieties of Stephen King's fiction, and underlying whatever makes his readers afraid, there are severe wounds. His prime contribution to American fiction is being a curator of generalized instabilities and of what induces personal and social fears both in America and around the globe. His juvenilia capture, even if a bit late, the fears of nuclear disaster that characterize Hollywood in the 1950s, adorning the theme with references from $H$. P. Lovecraft and other pulp authors, and his novels chronicle the United States in the late twentieth-century from the point of view of popular literature. Carrie explores adolescence and high school experience, It addresses childhood and the nature of fear itself, and Misery represents the dread of many writer and public figures. One of the most pernicious wounds in King's fiction, however, is not in his ostracized adolescents, his infant characters, or his writers-it is in his men.

Throughout his stories, King treats masculinity as a systemic problem. Because of the injuries, the damage, the pain, and the grief that male characters cause both to themselves and to others, masculinity is frequently correlated to immorality and accompanied by negative assumptions. Some novels question these assumptions, exposing the flaws of stereotypical representations of manhood, while other works are less critical, perpetuating these patterns.
Politics of otherness in Stephen King's fiction tend to involve diverse but united groups representing good. In It, for instance, atonement is reached through a union that represents humankind's ability to form cohesive groups not despite differences, but because of them. Problems a rise, however, when we scrutinize the representation of some social groups and the specifics of their contributions to this alleged cohesion. Far from being openly prejudiced, his novels tend to have patterns that simplify certain aspects of social identity (e.g., race, age, gender) into stereotypes. Some of those types are relatively unproblematic, such as King's imaginative children or his writers. They represent common tropes and themes, or even the status quo of a certain age. Others, however, are constructed on one-sided assumptions about social groups, in which case the generalizations become more harmful. One of these social groups is composed of King's traditional male characters, who establish their masculinity as the positive image of a negative that is the unmasculine, untraditional other.

Even though manhood is a frequent topic in King's novels, there are significant gaps in the criticism. The analysis related to gender initially focused on characters from his older novels, and only recent critical works encompass the entirety of King's oeuvre. Most of them, however, are theses and dissertations covering the evolution of female characters. 
While several critics have written about male characters in The Shining and in Pet Sematary, making observations that are true to King's writing in general, there is no work centered on the development of men and masculinities in his novels. The closest is Tony Magistrale's chapter "Sex with Consequences: Sexuality and Its Discontents," from Stephen King: America's Storyteller, in which discussions about sexuality veer into problems of masculinity. Kate Sullivan's “Stephen King's Bookish Boys: (Re)Imagining the Masculine," is shorter, less broad, but equally useful. Since critical material on male characters is scarce, any analysis of masculinity in King's fiction can draw heavily on these two texts.

This article is a revised version of the third chapter of my MA thesis, Masculinity as an Open Wound in Stephen King's Fiction. My thesis argues that masculinity is depicted as an open wound-or unsolvable problem - in King's fiction, since many solutions are offered to serious predicaments, but none produces a coherent alternative for harmful masculine practices. One example, which I develop throughout this article, is how acceptance of difference in King's stories wrongfully presupposes a harmful essential difference. The study I conducted in my MA is ample and comprehensive in terms of literary facts and analyses, as it focuses on five novels but addresses dozens of King's texts. Therefore, while this article concentrates on The Shining, Pet Sematary, and
BELO HORIZONTE
N. 3
Doctor Sleep, I rely on more than thirty texts written by King in order to establish a thorough argument. Readers less fa miliarized with King may feel the generalizations a re too broad, but they are justified because King's extensive body of work lacks criticism of masculinity in such encyclopedic terms. I a m aware of the generality of this article-of its constraints and benefits. I hope the latter offset the former.

\section{HOMOSOCIAL RELATIONSHIPS, HOMOSEXUAL}

\section{UNDERTONES, AND HOMOPHOBIA}

In King's novels, sexuality is one indicator of good and evil. ${ }^{1}$ If we wish to gauge the morality of characters, we only need to investigate their sexual practices, not because expressions of sexuality in real-life have any inherent mora value, but because King assigns to them such values in his novels. Sound discussions on morality and sex tend to touch matters of consent and boundaries, applying ethical thinking to specific scenarios. In King's works, however, certain sexual inclinations presuppose moral or immoral qualities. What is considered normal sexuality indicates good character and having allegedly abnormal sex is only for evil people. Concluding a chapter about sexuality in King's fiction, Magistrale remarks that "sex in Stephen King never just is, but instead exists metaphorically, in constant service to the author's larger narrative and moralistic designs". ${ }^{2}$ Trouble starts when definitions of "normality" remain unchecked.
1. Whenever I refer to good and evil in this article, I do so recognizing that, even though they repres a continuum intersected by several others, King's fiction tends to present a dichotomic view of morality. As my aim is King's representation of morality, but rather examine manhood and sexuality in moral terms,

it would be counterproductive and nonsensical to constantly go against the notions King sets for his fiction. I would rather, in this article, recognize them for what they are and advance my discussion. This means I neither accept them in their entirety nor engage in unfruitful fights against King's presuppositions.

2. MAGISTRALE. Stephen King America's Storyteller, p. 90. 
3. MAGISTRALE. Stephen King: America's Storyteller, p. 82.
Throughout King's stories, male homosexuality is systematically presented as extremely peculiar, almost exotic or monstrous, since his gay men tend to have an immora mentality and speak in a lewd tone. Magistrale points out that

King's treatment of homosexuality throughout his literary career has been particularly less than enlightened. I can think of no evidence of gay or lesbian relationships that King portrays as mature, morally responsible, or loving, but there exist plenty of examples to assert that he employs homosexuality as a metaphor for oppression, and this is especially true in the context of adult male homoeroticism. ${ }^{3}$

It would be reasonable to expect Magistrale's examples to illustrate oppression by focusing on homosexuals being oppressed, but he mentions the gay men who assault the protagonist in "Rita Hayworth and Shawshank Redemption" and the homosexual undertones in the warped master/apprentice relationship between a Nazi and a sympathizer in "Apt Pupil". This reveals that, while there a re examples of gay men being oppressed in King's stories (Adrian Mellon and his partner Don Hagarty a re victims of hate-crime in $I t$ ), homosexuality tends to be portrayed as a deviancy that opens doors for dire consequences. Either way, gay characters tend to be reduced to their sexuality in stories that deal with homosexuality only tangentially and characterize it as corrupt. This is a fault King shares with many writers.

King's novels set gay people apart from those who are depicted not only as heterosexual, but as normal. Problems of masculinity afflict most of King's male cha racters, but his gay or bisexual men are specifically depicted as sexually depraved. In The Shining, Horace Derwent, the former owner of the Overlook Hotel, who has connections to organized crime and was responsible for the masked ball the ghosts make Jack Torrance revisit, has his bisexuality connected to abuse and crime. Horace is "AC/DC"4 and has a warped dominant/ submissive relationship with a man named Roger, who is "only DC" and accepts humiliating behavior hoping for a sexual relationship. Horace, however, never has sex with the same man twice, or "never goes back for seconds [...] not on his DC side, anyway". Their relationship is characterized in terms of a lust that overpowers self-respect and Roger's suffering is hinted at by "sounds [that] came hollowly out of the [dog] mask's stylized snarling mouth" a mong which are what "might have been sobs or laughter". ${ }^{5}$ Dick Hallorann's grandfather in Doctor Sleep is another example, as he bites and burns his grandson while alive, and, after his death, returns "with his half-rotted prick all rared up [sic]" ${ }^{\prime}$ and invites his grandson to have sex with him. Magistrale, commenting on
4. KING. The Shining, p. 514

5. KING. The Shining, p. 495

KING Doctor S/eep, p. 18 
7. MAGISTRALE. Stephen King: America's Storyteller, p. 85. the sexual compulsion of King's gay men, observes that "[t]his compulsion [...] should be viewed not just as an extension of their need to dominate others sexually; it is also a means for King to distance these characters from any degree of reader/ viewer sympathy". Instead of reducing the gap between different forms of sexuality, King represents non-standard sex based on a narrow admission of what is standard to begin with. Not every gay man in King's novels is an abuser, but even the exceptions reveal problems in the representation of sexuality.

Even when these gay men cannot be reduced to their sexual depravity, they remain essentialist in other respects. A recent example is Ollie in "Mister Yummy," who is gay, is not abusive, but remains a cliché. In King's short story, Ollie, an old gay man residing in an assisted living center, foresees his upcoming death and shares this information with his friend Dave. His knowledge comes in the form of a vision of the most attractive person Ollie has ever seen: a young man he met during the 1980s. A few days after telling Dave about his experience as a gay man, he passes away. After Ollie's death, Dave has a vision of a beautiful woman he met when he was young; he knows his death is coming. On the one hand, King touches issues such as the AIDS epidemic and presents heterosexual and homosexual fantasies on the same level. In this sense, "Mister Yummy" avoids King's simplistic representation of gay cha racters as the abnormal other. On the other hand, the story generalizes about gay people, attributing to Ollie an unreal lack of complexity. Dave, for instance, notices Ollie's sexual orientation because of gestures and body language. "It's the way you walk", Dave thinks. He adds that it is also because of the "still-life drawings in your room", ${ }^{8}$ but digresses and only traces a logic connection between Ollie's increasingly bad art and the loss of his motor abilities after old age. Dave's connection of homosexuality and a certain gait or artistic perspective is never explained by the short story, but rather confirmed by the fact that Ollie is indeed gay. While in the real world these assumptions a re somewhat correct at best, and, at worst, a re fruit of confirmation bias, in "Mister Yummy" they are factual and reductive. The assumption that gay men have a specific worldview or a favorite form of artistic representation, when read in context, only reaffirms the essentialism surrounding King's homosexual male characters.

Unconventional forms of sexuality are generally linked to immorality in King's books. Commenting on Ca role Senf's "Gerald's Game and Dolores Claiborne: Stephen King and the Evolution of an Authentic Female Narrative Voice”, Will Napier observes that, in Gerald's Game, the protagonist's history of being abused by her father as a child 
9. NAPIER. The Haunted House of Memory in Stephen King's Fiction, p. 47.

10. For a summary of this discussion, see SEDGWICK. Between Men, p. $5-11$.

11. MAGISTRALE. Stephen King: America's Storyteller, p. 90 structured her subsequent relationships, which ultimately led her to marry an exploitative man-the Gerald of the title whose bondage game she plays against her will-and to the tigh spot in which she finds herself for so much of the novel, handcuffed to a bed recalling her life. (emphasis added) ${ }^{9}$

The bondage game, an expression of sexuality described either as consensual and healthy or as responsible for perpetuating oppressive power relations, ${ }^{10}$ is here definitely associated both with sexual abuse from the past and with sexual abuse in the present, as there is no consent in its execution. Magistrale comments that

As is the case for many Americans, sex in Stephen King is either cloyingly romanticized-locked in the domain of rarified white, bourgeois marriages, such as those found in Bag of Bones and Lisey's Story - or it sinks to the level of vulgar appetite, in the form of brutal male rape assaults, both heterosexual and especially homosexual, and femme fatale duplicity. ${ }^{1}$

The problem, therefore, is not only the representation of sex or sexual orientation, but also the assumptions behind the entire concept of sexuality, which are, in turn, one of many problematic manifestations of masculinity in King's works.
These distorted depictions of sexuality and maleness, however, are not exclusive to the fiction of Stephen King, but rather the product of a literary view he perhaps shares with other writers of the genre. In his non-fictional Danse Macabre, King defends that "if the horror story is our rehearsal for death, then its strict moralities make it also a reaffirmation of life and good will and simple imagination-just one more pipeline to the infinite". ${ }^{12}$ Magistrale remarks that, in the film adaptations of King's works, there is no "pipeline to the infinite", but rather a doom that closes in on the lives of characters. This applies to his works in general, adapted or in the original. King's affirmation rings true, but only as a general sense of the accomplishments and failures of horror literature. If horror "reaffirm[s] the virtues of the norm", it also, on closer inspection, reveals how the normal only exists because of the abnormal. While it seems adequate that we have our qualities reaffirmed in contrast with evil characters such as Norman Daniels, who commits numerous crimes, this comparison does not extend to areas that lack inherent moral indicators, such as sexuality. Assuming there is any innate lack of morals in non-standard sexuality is a mistake that backfires, as some readers, instead of having the virtues reaffirmed, may have social aspects of their identities misrepresented, being left to wonder why bondage or homosexuality are so evil. 
13. STRENGELL. "The Ghost: The Gothic Melodrama in Stephen King's Fiction", p. 227.

14. PUNTER. The Literature of Terror, p. 14.
What, however, is the extent of this problem? Should we blame King himself? Should we bla me commercial literature, or horror fiction, or none of those? While part of the problems with King's representation of masculinity stems from the content of his novels, it remains that both content and form have been influenced by stereotypes from Gothic literature and its contempora ry developments. Heidi Strengell, for instance, following her arguments about King's use of free will as a literary resource, observes that he "clearly embraces the moral stance of [Peter] Straub's ghosts, which, like that of most horror fiction, is firmly reactionary and defends traditional values". ${ }^{13}$ King's stories fit into a view of the Gothic less as a time-fixed genre and more as a mode of writing as described by David Punter, ${ }^{14}$ so readers should read The Shining and Pet Sematary with Gothic conventions in mind. Their passive heroines, their hero-villains, and the uneasy history behind their evil places all have ancestors in Gothic literature. At least partly, then, King's defective representation of manhood can be traced to a history of similar stock characters and repeating themes.

King's use of Gothic characters is often accompanied by ironic inversions, but not to a point in which the underlying structure is changed. Based on observations by Punter, Joanna Russ, and other scholars of Gothic literature, Kimberly Beal connects King's writing to numerous Gothic elements, from evil places to stock characters, among them heroines, heroes, and male villains. She observes,

King's use of Gothic's stereotypical characters and elements is extensive and covers nearly all of his works, indicating not only that he fully understands the elements that make up the Gothic, but also that he can use them to create interesting and terrifying tales. ${ }^{15}$

The fragility of Gothic heroines (e.g., Wendy Torrance in The Shining), the perversion of hero-villains (e.g., Jack Torrance), and cursed or haunted characters (e.g., Louis Creed in Pet Sematary, Danny Torrance in The Shining and Doctor Sleep), as well as the general sense of dread of premonitions and the dark landscapes of New England, they form an atmosphere that readers recognize worldwide. Even if one of King's hallmarks is the use of Gothic stereotypes, his na rratives ra rely question their own premises. Beal argues that, in King's stories, as in contemporary Gothic fiction, "the elements of the Gothic are altered, updated, or otherwise manipulated into somewhat unrecognizable representations of the original Gothic element". ${ }^{16}$ This may be true but those changes a re limited to specific elements, such as the role of the fragile heroine in The Shining being replaced by a self-sufficient character in Rose Madder. Old castles are also replaced by hotels (The Shining and "1408") and the
15. BEAL. "Sometimes Being a Bitch is All a Woman Has": Stephen King, Gothic Stereotypes, and the Representation of Women, p. 18.

16. BEAL. "Sometimes Being a Bitch is All a Woman Has": Stephen King, Gothic Stereotypes, and the Representation of Women, p. 18. 
dangers of a ncient, hidden knowledge often blend in with informational overload and fear of technology ("Ur"). The characters, places, and objects are never the same; the assumptions behind them, however, tend to remain unchanged, especially those that relate to sexuality.

Even if some characters go through changes that contest stereotypes, this revision often comes at the expense of other characters, as if some element had to be anchored not only to the general conventions of the Gothic, but also to its gendered stereotypes. Beal's exa mples of King's reworking of the Gothic involve female characters who "are forced to become bitches: women who will do whatever it takes to save themselves and those they love, with no remorse or regrets". ${ }^{17}$ The powerless heroines from traditional horror stories, then, become self-sufficient women who have the means to revert their situation. Some male characters, too, go through changes, as

d] espite the obvious similarities of domination, these two tyrannical figures [from Rose Madder and Dolores Claiborne] differ greatly from the tyrants of the classic Gothic because, whereas the classic Gothic tyrants have unlimited resources that allow them to assert their control over the female protagonist, the men in these novels are forced to rely on their own ability to lie and manipula te others in order to cover up thei deeds and keep their families from revealing their abuse. ${ }^{18}$
While the structure of female characters is altered, as they go from simple target to people who can respond to threats, the change in male characters hardly seems sufficient, as they merely must choose from a different skill se to continue their villainy. Lying and manipulating comes at no moral expense for Norman Daniels in Rose Madder for example. Readers are led to believe, in fact, that, had he murdered Rose, his position as a police officer would have granted him favors and immunity. It would not, after all, be his first homicide. Men remain stereotypes, as if to provide a foil for the realistic depiction of women, the same foil that women, in turn, often provide for complex men in King's older novels. Perhaps because of the tendency horror fiction has of maintaining the status quo (or because of King's belief that it does), social criticism in King's work often changes the realization of traditional patterns, but ra rely the patterns themselves. Rose Madder only reinforces the male/female opposition of some Stephen King's novels, which I discuss in the following section.

This restrained depiction of sexuality, however, neither contaminates other aspects of King's social criticism nor seems to be a part of a larger deficiency. Magistrale makes two observations on this point. First, he writes,

As a chronicler of postmodern Americana-particularly those elements in American culture that tend to provoke
17. BEAL. "Sometimes Being a Bitch is All a Woman Has": Stephen King, Gothic Stereotypes, and the Representation of Women, p. 27. 
19. MAGISTRALE. Stephen King: America's Storyteller, p. 89.

20. Sarah Nilsen identifies in the filmic adaptation of King's The Green Mile the stereotype of the "Magical Negro," an overly virtuous black character, often endowed with supernatural abilities, who serves or supports a white character, usually the protagonist. Informal online essays on King's fiction corroborate Nielsen's observations, noting that Dick Hallorann (The Shining) and Mother Abigail (The Stand) fit the stereotype. controversy and challenge norms and assumptions-King's attitude toward sexuality is remarkably staid. While highly attuned to the negative abuses that often characterize heterosexual marriages and the worst homoerotic compulsions, the writer is, on the other hand, closed to portraying liberated constructions of either homosexual or heterosexual unions. ${ }^{19}$

If we compare the representation of gender and sexua lity to the representation of characters of different nations, ages, or social classes, we find less problems with the latter than with the former. King's older characters, for instance, usually have an informal kind of wisdom, as we see in Jude Crandall (Pet Sematary), Dick Hallorann (The Shining), and Abagail Freemantle (The Stand), but they are not always perfect. There are unscrupulous old men, such as Charles Jacobs (Revival), Taduz Lemke (Thinner), Dick Hallorann's grandfather (Doctor Sleep), and George Winston ("Morality"). Other old characters, such as Phil and Pauline ("Herman Wouk Is Still Alive") a re neither wise nor evil, but everyday people, with commonplace flaws and positive traits. Critics also identify problems in the representation of characters from different ethnicities, but, while those critics, for instance, criticize the oversimplified image of black people, Magistrale criticizes King's view of sexuality itself, not only the characters who bring it to life. King portrays black characters as stereotypes, ${ }^{20}$ but does not indicate problems in blackness and does not suggest some ethnicities should be avoided. The same is not applicable to sexuality, which, as a concept, it characterized traditionally and restrictively, forcefully separating "us" and "them”. Magistrale's second observation is that

[t]he severity of King's judgment [regarding sexuality] here might be tied to his career-long association with the Gothic, wherein transgressions against the status quo-particularly sexual transgressions-result in horrific consequences; or perhaps it is the influence of the writer's strong Methodist upbringing, or the ambiance of New England Puritanism with which King has lived nearly his entire life. ${ }^{21}$

Despite having substantially shaped contemporary horror fiction alongside authors such as Richard Matheson, Ray Bradbury, and Lovecraft, King remains latched onto Gothic fiction, its familiar faces, and its familiar problems.

Our initial tendency may be to recognize this as a major flaw of King, his colleagues, and their genre, and Magistrale's arguments indicate the plausibility of this approach. A different view, however, shows that perhaps King is aware of such flaws and understands them as a necessa ry consequence of his less serious approach to writing. In his review of Mr. Mercedes, Tim Parks compares King to more serious authors, but his conclusion is less judgmental
21. MAGISTRALE. Stephen King: America's Storyteller, p. 76. 
22. PARKS. “The Pleasures of Reading Stephen King", p. 27.

23. PARKS. "The Pleasures of Reading Stephen King", p. 27 of King's value and more descriptive of his method. Parks comments on the predictability of the plot in Mr. Mercedes, on its extensive use of detective novel tropes, and on its simplistic distinction between good and evil, then asks, "Could it be that King is deliberately preventing us from taking his stories too much to heart?”. ${ }^{22}$ Echoing King's remarks on the morality of horror fiction, Parks observes that "we good folks, who always feel a little guilty when we do something mean, can relish the utter destruction of our utterly evil enemy without any qualms or misgiving," all that while "the reader knows [the story] is not true". ${ }^{23}$ While this does mean King is freed from the responsibility of writing stock characters and depicting some components of human identity simplistically, it at least provides us with some perspective. A strange aspect of writing about Stephen King's novels is assuming his literature is worthy of academic analysis while understanding that this does not mean we should write about King as we write about Shakespeare or Dostoyevsky.

It remains, nevertheless, that troubling patterns accompany King's one-sided depiction of non-standard sexuality. From an extradiegetic standpoint, we see that the logic behind the representation of homosexual characters im plies that homosexuality is immoral. On a diegetic level, King's male characters sustain homosocial relationships that are ridden with homophobia as a means to repress, shun, or hide their own homosexuality: uncannily, they see in the other a part of themselves they wish to erase or deny. Sullivan, in her article on King's depiction of masculinity in relation to femininity, concludes that he

understand[s] authentic manhood to be diametrically opposed to either female embodiment or gay male identity. Thus, what could be a progressive move-the expansion of ideal masculinity to include stereotypically feminine attributes and behaviors-is yoked to both cultural misogyny and homophobia. ${ }^{24}$

Separating masculine and feminine, or putting some masculinities in opposition to others, may be an invitation to examine intricate constituents of manhood, but only when gender difference is seen not as absolute, but as circumstantial.

While Sullivan's observations are well structured, capturing the gist of manhood in King's works, other critics, seeking psychoanalytical explanations for the behavior of characters, tend to rely on negligible textual content as evidence, resulting in impla usible readings. Steven Bruhm, for instance, establishes a Lacanian reading of The Shining involving the father's unrecognized homoerotic desire toward his male child as cause of the familial collapse. According to Bruhm, "By placing Danny and Jack in the arena of historically entrenched male homosocial relations,
24. SULLIVAN. "Stephen King's Bookish Boys: (Re)lmagining the Masculine", n.p.

$\begin{array}{llllll}\text { EM TESE } & \text { BELO HORIZONTE } & \text { v. } 23 & \text { N. } 3 & \text { SET.-DEz. } 2017 & \text { SANTOS. Sexuality and sociability in Stephen King's fiction }\end{array}$


25. BRUHM. "Picture This: Stephen King's Queer Gothic", p. 470.
King documents the anxiety over this forced male proximity, an anxiety that gradually yields psychic dissolution and collapse". ${ }^{25}$ Sexual anxiety, indeed, is abundant in The Shining. We find it in Jack's homophobia and in the sexualized ghosts of the hotel. Bruhm's psychoanalytical approach, however, relies on a sexual connection between father and son that the novel states only vaguely, if at all. The Shining provides numerous other sources for the "dissolution" and the "collapse" of the Torrances other than their sexual complications: historical unease, physical abuse, trauma, alcoholism, lack of responsibility, and conflicts related to work and social classes. To reduce The Shining to sexuality is to neglect other angles of American masculinity as it was settled in the twentieth century.

I concede that suppressed homoerotic desire often involves open displays of homophobia, but the plausibility of such correlation does not indicate it always exists, even if the pattern is frequent in King. Eve Kosofsky Sedgwick notes,

much of the most useful recent writing about patriarchal structures suggests that "obligatory heterosexuality" is built into male-dominated kinship systems, or that homophobia is a necessary consequence of such patriarchal institutions as heterosexual marriage and she then reminds us, "[n]evertheless, it has yet to be demonstrated that, because most patriarchies structurally include homophobia, therefore patriarchy structurally requires homophobia” ${ }^{26} \mathrm{~A}$ similar argument can be made for homophobia often involving suppressed homoerotic desire, but not necessarily requiring it. Bruhm's article, while useful in its observations about the antithetic nature of homophobic masculinities, seems to excavate Jack's and Danny's psyche for answers to questions the novel already elucidates more directly. It is reminiscent of Sedgwick's observation that, "[t]o assume that sex signifies power in a flat, unvarying relation of metaphor or synecdoche will always entail a blindness, not to the rhetorical and pyrotechnic, but to such historical categories as class and race". ${ }^{27}$ Bruhm's arguments are not necessarily unsound, but dig too deep for answers that are on the surface.

Alegre, commenting on Bruhm's article, observes that, even if he is right, he suggests an unreachable state for masculinity awareness. She observes,

Bruhm may be right, but his thesis-that the relationships between men are distorted by their difficulties to acknowledge basic homoerotic impulses-is used to criticise King rather to explain [sic] the context from which his fiction arises
26. SEDGWICK. Between Men, p. 3-4.

27. SEDGWICK. Between Men, p. 10- 
28. ALEGRE. "Nightmares of Childhood: The Child and the Monster in Four Novels by Stephen King", p. 109

29. MAGISTRALE. Stephen King America's Storyteller, p. 85

30. KING. Rose Madder, p. 72 and comments, "Bruhm proposes reaching a stage of liberalism which is radically utopian, in which men are in touch with all their feelings" ${ }^{28}$ Even if Bruhm's reading recognizes the interplay of homosociality and homoeroticism in King's stories, it works more as an exercise on possibility than as a sensible textual analysis, since it overstates tensions at which The Shining merely alludes, seeking a sexual dimension for problems that are connected to sexuality only to a small extent, if at all.

Other novels are more explicit about the relationship between homophobia and repressed homosexuality. Magistrale mentions a "nexus King forges between out-of-control (homo)sexuality and malefic intent" ${ }^{29}$ that includes characters from The Green Mile and to which I add Norman Daniels, from Rose Madder. Norman's aggression toward people is of sexual nature and his violence toward men indicates homosexual desire behind his homophobia.

Norman's focalization is contaminated by his self-asserted superiority, to which readers access through his view of secondary characters as inferior animals. When Norman is in a park interrogating a man who saw Rose leave the city, the narrator describes the witness as feeling "like one of the three little pigs sitting on a park bench next to the big bad wolf".$^{30}$ Here Norman is not the focalizer, but, as he hurts the witness by clutching his testicles and states that "You fags don't like getting hit, do you?", ${ }^{11}$ it becomes clear that his aggressive superiority is, in his mind, not only physical, but also related to masculinity. He is a man, while the witness, as Norman states, is "just a greasy little halfbreed cockgobbler". ${ }^{32}$ Gay and weak men are equated to pigs, while heterosexuality and virility are wolfish. The narrative does not corroborate these correlations, but rather makes us understand how they sprout from the minds of characters whose notions of manhood are discriminatory.

Behind Norman's anti-gay views, however, is the sexual pleasure he derives from torturing other men. When he refers to Peter Slowik, the man who helps Rose find a shelter for abused women, two labels stand out: the name "Thumper" and the term "Jewboy". The first refers to a character from Disney's Bambi. Thumper is a rabbit, which is yet a nother instance of Norman referring to men in terms of small a nimals. The second term also connects Slowik's Jewishness to being less than a man. When he murders Slowik, Norman, who "wasn't very surprised to find he had a raging hardon," 33 bites him "over three dozen times" and leaves him with "at least one part of his anatomy [...] missing". ${ }^{34}$ The process escalates to a point in which "half of [Norman's] face was covered with blood and hair and little tags of skin". ${ }^{35}$ Later, Norman still has "no idea how much forensic evidence he might have left downstairs in the
31. KING. Rose Madder, p. 73.

32. KING. Rose Madder, p. 71
KING. Rose Madder, p. 153.

34. KING. Rose Madder, p. 217.

35. KING. Rose Madder, p. 154. 
36. KING. Rose Madder, p. 154.

37. Peaking during the 1980 s and 1990s, the movement, based on Jungian archetypes, advocated for a therapeutic approach (involving retreats and workshops) to connect emotionally wounded men to a masculine essence that was allegedly lost because of, among other reasons, the Vietnam War and feminism (CARROLL, American Masculinities: A Historical Encyclopedia, p. 302-03).

38. SULLIVAN. "Stephen King's Bookish Boys: (Re)lmagining the Masculine", n.p.

39. SULLIVAN. "Stephen King's Bookish Boys: (Re)lmagining the Masculine", n.p. basement". ${ }^{36}$ The connotation is less than subtle: biting off Slowik's penis and possibly leaving saliva and semen in the crime scene connects Norman's animalistic impulses to a veiled homosexuality that is expressed in unhealthy forms, as is common in King's works.

The problems of masculine sociability in King's novels are not confined to the masculine sphere, since certain arguments for male liberation imply the exclusion of the feminine. Sullivan reads King side by side to the Mythopoetic Men's Movement ${ }^{37}$ and recognizes how the difficulty of establishing communication and closeness is part of the discourses of both the mythopoets and King's characters. She observes, "Part of the difficulty in sustaining male intimacy, according to [the Mythopoetic] men's movement theorists, is the lack of safe spaces to express such emotion". ${ }^{38}$ Intimacy and communication, however, are insubstantial concepts that, in the context of masculine revisions, may form dishonest a rguments, as if silent men were the victims of some external social pressure rather than people responsible for an internal failure of masculinity. In addition, Sullivan quotes from Michael Schwalbe's "Mythopoetic Men's Work as a Search for Communitas”, in which he explains how the work of mythopoets who long for masculine connections "reaffirms the lesser value of women whether this is intended or not". ${ }^{39}$ Because of their belief in funda mental distinctions between men and women, mythopoets construct an argument in which men connect to each other in retrea ts not only to recapture masculinity, but also to reject femininity. Closing her argument, Sullivan notes how "Schwalbe's observations about the men's movement also explain why [in King's "The Body"] Gordie's relationship with his wife is so peripheral-women have "lesser value' and cannot understand or appreciate male truths". ${ }^{40}$ Behind some of King's characters and their exclusion of femininity, which I will explore in the next section, is their wish to reinforce masculinity via contact with other men only. While King's male characters are often non-traditional and not "football players or any other version of empowered masculinity", ${ }^{41}$ the shortcomings of their views on communication remain. In "The Body," as Sullivan notes, "intimacy [...] is difficult to sustain, and the novella posits that male love, although desirable, is also unstable and even untenable" ${ }^{42}$ This is a moment in which the wound of masculinity seems about to close, only to reassert its openness. It is the same weakness of a logic that sees communication as a solution: there is an attempt at shifting the cause of the problem to society (or women, or the other), but there is no honest endeavor to remodel masculinity from within.

In the masculinities of King's novels, the ultimate other is the gay man. Homophobia sets the limits and definitions
40. SULLIVAN. "Stephen King's Bookish Boys: (Re)lmagining the Masculine", n.p.

41. SULLIVAN. "Stephen King's Bookish Boys: (Re)Imagining the Masculine", n.p.

42. SULLIVAN. "Stephen King's Bookish Boys: (Re)Imagining the Masculine", n.p.

$\begin{array}{llllll}\text { EM TESE } & \text { BELO HORIZONTE } & \text { v. } 23 & \text { N. } 3 & \text { SET.-DEz. } 2017 & \text { SANTOS. Sexuality and sociability in Stephen King's fiction }\end{array}$


43. KING. The Shining, p. 29. America's Storyteller, p. 84 via negation: whatever the true man is supposed to be, he is certainly not gay. Watson, the in-season caretaker in The Shining, summarizes the matter when he asks Jack, "Say, you really are a college fella, a ren't you? Talk just like a book. I admire that, as long as the fella ain't one of those fairy-boys". ${ }^{43}$ While King's male characters a re overly careful not to have their camaraderie confused with eroticism, they do admire, envy, or even crave the company of other men. As Magistrale points out, many of King's most solid social unions are homosocial rela tionships involving male writers. "[I]ronically," Magistrale writes, "some of the strongest and most life-affirming unions that take place in this writer's world occur in same-sex relationships". ${ }^{44}$ If we extrapola te to characters other than writers, we see that, in Blaze, Blaze and George are a fitting example of such "life-affirming unions", even though the appropriateness of their friendship is questionable, as George is a negative influence. Flashbacks also reveal how close Blaze was with a childhood male friend, whose significance is illustrated in the chapter in which they both leave their orphan house and travel to Boston, sharing adventurous experiences common to King's young characters.

The Body, Duma Key, "Rita Hayworth and Shawshank Redemption," and the Dark Tower series are further examples of how male homosocial relations are endorsed and even idealized. As I mentioned, however, "Shawshank Redemption" and The Body establish these relations at the expense of gay men. As Sullivan observes, "In 'The Body,' homosexual panic is marked by the boys' excessive concern with proper masculinity". ${ }^{45}$ She mentions how Arthur Biddle, in "The Mythic Journey in 'The Body," sees the boys' "frequent teasing about being 'pussy' or 'queer" ${ }^{46}$ as a form of distancing their male companionship from eroticism. Sullivan also remarks "The boy's repetitive taunts to each other about effeminancy [sic] reflect a common theme in King and in the mythopoetic men's movement: the fear that male emotion or sensitivity will be construed as homosexuality" ${ }^{47}$ Homophobic tendencies do not appear despite the transformative and non-romantic companionship of King's male characters, but together with it. One side of the relationship feeds off the other, revealing how the social nature of masculinities in King's oeuvre renders them incurable.

\section{MALE/FEMALE RELATIONSHIPS}

Stephen King's works are marked by a constant friction between the masculine and the feminine. Even his short stories often focus on the marital problems of his almost exclusively heterosexual couples. When King's men and women are not arguing with each other regarding trivial subjects ("Premium Harmony") they have their marital stability
45. SULLIVAN. "Stephen King's Bookish Boys: (Re)lmagining the Masculine", n.p.

46. Quoted in SULLIVAN. "Stephen King's Bookish Boys: (Re)lmagining King's Bookish Boys:
the Masculine", n.p.

47. SULLIVAN. “Stephen King's Bookish Boys: (Re)Imagining the Masculine", n.p.

$\begin{array}{llllll}\text { EM TESE } & \text { BELO HORIZONTE } & \text { v. } 23 & \text { N. } 3 & \text { SET.-DEz. } 2017 & \text { SANTOS. Sexuality and sociability in Stephen King's fiction }\end{array}$


permanently destroyed by external agencies, be they dead rock-and-roll musicians ("You Know They Got a Hell of a Band"), an immoral sadistic reverend ("Morality"), or even frogs with sharp teeth ("Rainy Season"). In the rare occurrence that happiness takes center stage, one of the characters is promptly removed, usually via catastrophes. In the Dark Tower series, Eddie, an ally whom the protagonist rescues and trains, dies and disrupts the unity of the group, leaving his wife Susannah especially scarred. In Blaze, childhood love is as brief as any other comforts of the main character. The broken homes in It are additional exa mples, as are the accidents that contribute to the separation of the main romantic couples in Duma Key and Dead Zone. King's novels depict men and women as inhabitants of different worlds who, when in contact, will clash.

Like King's representation of male homosocial and homosexual relationships, the interactions between men and women in his novels exemplify both his moralistic views on sexuality and the problems of defining the self via the other. The presence of female characters, while assuring their male partners' public and open heterosexuality, also help define masculinity based on the exclusion of the feminine. Sullivan compares the rejection of homosexuality with the rejection of the feminine, noting that "[e]ither the homosexual threat intensifies [...] or in the case of King's more overt horror, the mediation of the threat shifts to female and/or queer monstrosity". ${ }^{48}$ While they are bothered by the supposed risk of being labeled homosexual, King's groups of men relish the opportunity of being unrestrained by feminine figures. Louis Creed wishes to leave his fa mily behind, and Jack Torrance hides the Overlook journal from Wendy, as Gordon LaChance hides his tears from his wife in The Body - these are part of a pattern of male/female relationships characterized by miscommunication and avoidance.

In terms of social relations, manhood in King's stories is constructed on a framework of extreme differences, of which the most severe are between men and women. This is ingrained into the assumptions of his older stories, while his newer books tend to question this logic in their critical representations. They cease to be the assumptions behind the novel and become the assumptions of characters. Nevertheless, manhood is constituted in essential opposition to femininity.

Functioning like the homophobic panic that surrounds King's narratives, the presence of femininity is used by male characters as a public assurance of their own traditional heterosexual masculinity. Homophobia is a divider between homosocial and homosexual relationships in King's stories, establishing proper and improper social interactions based on bigotry. While male characters yearn for contact with
48. SULLIVAN. "Stephen King's Bookish Boys: (Re)lmagining the Masculine", n.p. 
49. Quoted in GUTHRIE. Three Decades of Horror: Domestic Evolution of Female Characters in Stephen King's Fiction, p. 28.

50. KING. The Shining, p. 20 other men, be it through a history of masculinity like the Overlook's or through a nostalgia regarding all-male childhood groups of friends like those of "The Body", they try to "balance" these needs with a restatement of their heterosexuality. They may be part of a group of men, but they are openly homophobic to avoid being seen as gay. King's depiction of femininity often has the same purpose: to restate traditional masculinity. When writing about Wendy Torrance's agency in his thesis about female characters in King's fiction, James Guthrie quotes from Jackie Eller who explains, "Enhancing the strength of the male lead, King contrasts his fictional husbands with pathetic wives or partners, individuals who are not quite able to accept or deal with the events of horror [...] [Wendy's] main contribution is to highlight the more interesting male". ${ }^{49}$ This is not Wendy's only contribution to the novel, as she has a complex connection to her son, and the construction of her character provides insights into the household dynamics, but, primarily, she mostly exists in relation to Jack's masculinity. In remarks such as "If it's what your [Danny's] father wants, it's what I want" ${ }^{50}$ Wendy reveals that much of her character depends on Jack's. Other women, like Rachel Creed in Pet Sematary, also highlight the male protagonist's role, either in the way they are depicted or in the way they are treated by their husbands. The focus female characters give to men is based on contrast rather than on similarity.
More specifically, this dynamic relies on depictions of the feminine as an emasculating presence. In Pet Sematary, this is exemplified not only by Louis's sudden desire to leave his family, but also by his constant fear of emasculation. Erica Dymond remarks that, while "Louis' rash desire to flee his family soon dissolves [and, a]llegedly, the stress of the journey had overwhelmed his faculties [...] the feeling of emasculation lingers throughout the text, most prominently expressed through his profound castration anxiety" ${ }^{51}$ While I find most readings involving phallic symbolism and fear of castration in King's works unconvincing, this one is substantiated by textual evidence. Dymond, for exa mple, finds that the family cat "acts as a vehicle for Louis's fears", ${ }^{52}$ and quotes relevant passages, such as Louis's initial reluctance to have the cat castrated because his "strong feeling that it would destroy something in Church [the cat] that he himself valued - that it would put out the go-to-hell look in the cat's green eyes". ${ }^{53}$ Dymond concludes that, when Louis eventually accepts Church's castration and pins the veterinarian's number to the fridge, relega ting the appointment to be made by his wife, "he grants Rachel the power of emasculation" ${ }^{54}$ In King's fiction, female characters are not necessarily emasculating, but are seen as so by men, often in self-fulfilling prophetic ala rm. Some aggressive characters such as the nurse Annie Wilkes, who kidnaps and tortures the writer Paul Sheldon in Misery, can indeed be read in
51. DYMOND. "From the Present to the Past: An Exploration of Family Dynamics in Stephen King's Pet Sematary", p. 796.

52. DYMOND. "From the Present to the Past: An Exploration of Family Dynamics in Stephen King's Pet Sematary", p. 796.

53. KING. Pet Sematary, p. 22

4. DYMOND. "From the Present to the Past: An Exploration of Family Dynamics in Stephen King's Pet Sematary", p. 797.

$\begin{array}{llllll}\text { EM TESE } & \text { BELO HORIZONTE } & \text { v. } 23 & \text { N. } 3 & \text { SET.-DEz. } 2017 & \text { SANTOS. Sexuality and sociability in Stephen King's fiction }\end{array}$


55. BEYNON. Masculinities and Culture, p. 31.

56. BEYNON. Masculinities and Culture, p. 31 direct connection to emasculation, but Rachel Creed and Wendy Torrance are a source of fear for a castration that happens only through their own husbands' actions and only because of their disproportionate fear

Because of men's perception of emasculation, female characters are excluded from male environments, which only reinforces male/female opposition. Beynon's research on British masculinities and culture identifies a type of literature involving British imperial manhood and the exclusion of women. "For many writers of the period [from late Victorian times to World War I]", Beynon writes, "the Empire was the site of 'masculine imaginings' in which men could enjoy homosocial comradeship in physically challenging, arduous circumstances far from what they perceived to be the da maging influences of 'the feminine"'. ${ }^{55}$ This form of literature was (and its repercussions today often are) "overtly masculinist, didactic and (in our eyes) racist, written by Imperial men for their heirs" ${ }^{56}$ While contemporary readers and authors tend to be more skeptical about anti-feminine masculinities, Sullivan still identifies in King's "The Body" a search for male bonding that rejects the presence of women. In this sense, King's work is in tune with the Mythopoetic Men's Movement. Magistrale, however, attributes more responsibility to King's male characters. In his discussion about one of Karen Hohne's essays on
King's female characters, he agrees there is a clash between powerful forms of language involving King's male protagonists, but he also notes that "it is likewise true that his male protagonists use the silence of secrets-that is, the deliberate omission of language-to exclude women from narrative action" ${ }^{57}$ The scene in which Jack lies to Wendy about the scrapbook containing the Overlook's history is one example, as it ensures that the secrets of the hotel remain connected only to a history of unhealthy masculinity.

In her observations regarding American literature and the representation of heterosexual marriage, Alex Hobbs discusses how literature complicates the link between heterosexuality as part of hegemonic masculinity. While she relies on premises that are not necessarily true, her argument incites thoughts on the correlation between traditional manhood and the avoidance of women. Hobbs cites Leslie A. Fiedler's discussion on how American fiction is devoid of "adult heterosexual love". ${ }^{58}$ Fiedler argues,

the typical male protagonist of our [American] fiction has been a man on the run, harried into the forest and out to sea, down the river or into combat-anywhere to avoid 'civilization,' which is to say, the confrontation of a man and woman which leads to the fall to sex, marriage, and responsibility. ${ }^{59}$
57. MAGISTRALE. Stephen King: America's Storyteller, p. 116

58. Quoted in HOBBS. "Masculinity Studies and Literature", p. 391.

59. Quoted in HOBBS. "Masculinity Studies and Literature", p. 391. 
60. HOBBS. "Masculinity Studies and Literature", p. 392.
The argument involves two plausible premises-that heterosexuality is a characteristic of traditional masculinity, and that some male protagonists in American fiction tend to avoid the responsibility of marriage. Hobbs concludes that the average portrayal of men in American literature involves flaws of masculinity, which indicates that "hegemonic ideals are not left intact by literature as they may be in other cultural media, like advertising or film, for exa mple". ${ }^{60}$ This conclusion, however, does not follow the initial arguments correctly, as it overlooks how non-marital and non-monogamous romantic relationship may also characterize traditional masculinity. While "adult heterosexual love" is a core component of traditional masculinity, so is the figure of the unmarried heterosexual man who has multiple romantic or sexual encounters and strongly displays both his macho heterosexuality and what he sees as the freedom of being outside a relationship. Variations of this male figure live in the fantasies of Louis Creed when he considers abandoning his family and similar tendencies are seen in King's absent fathers. Avoiding women is not an escape of traditional masculinity, but rather a consequence of its core tenets: that women constrain men and that genders are so fundamentally different that they cannot coexist peacefully.

When masculinity embraces difference, it is always under the premise that there is inherent and inescapable difference.
When Jud Crandall, in Pet Sematary, comments that "[t]he things that are in a man's heart [...] are secret things [and that] any woman who knows anything at all would tell you she has never really seen into any man's heart" ${ }^{61}$ he is putting into words the logic behind King's representation of genders. This sentence is echoed in the words of Watson, the in-season caretaker of the Overlook, who says to Jack, "I wish I could be as charitable as my mother was [...] Me, I'm just as mean as a snake with the shingles. What the fuck, a man can't help his nature" ${ }^{2}$. Generalizations like these lead to forms of masculinity that are self-referential but not self-aware. By excluding the feminine without contesting the assumptions behind traditional masculinity and femininity, male characters tend to maintain their notions of masculinity without referring to alternatives and without realizing they are doing so. Magistrale comments, "King complicates Jack's response [to self-repression and alcohol abuse] by contextualizing it into very specifically gendered terms" in which "[w]omen a re associated with sobriety and punishment" ${ }^{63}$ In this sense, Jack's conflict with his alcoholism is also a conflict between his independence and his wife's restrictions. The tendency of King's male protagonists is to cut contact with women and disregard alternative masculinities, perpetuating their flawed manhood.
61. KING. Pet Sematary, pp. 173-4.

62. KING The Shining, p. 27

63. MAGISTRALE. Stephen King: America's Storyteller, p. 93. 
64. SULLIVAN. "Stephen King's Bookish Boys: (Re)lmagining the Masculine", n.p.
Without proper examination of what constitutes the feminine or the masculine, the already elusive alternative of embracing femininity becomes even more disadvantageous. Behind this option is the belief that masculinity and femininity naturally lack what the other possesses, having complementary essences. This reasoning assumes identities have simplistic essences, and it goes against notions of plurality. If the composition of masculinity and femininity go unchecked, and if we assign essentialist attributes to them, the result is the a mbivalence we find in King's logic: while men want to avoid emotional silence (portrayed as inherently masculine) and wish to give voice to their feelings (portrayed as inherently feminine), they also fear being seen as men who feel attraction to other men (also portrayed as inherently feminine). The problem lies in the assumption that these attributes, or any fixed trait at all, constitute masculinity or femininity. Similarly, Sullivan notes that "King's version of heroism necessarily departs from traditional definitions of masculinity to embrace stereotypic feminine qualities but not to such a degree as to construct the hero as homosexual". ${ }^{4}$ This is yet a nother practice that keeps the wound of masculinity open: problems of manhood are identified, but femininity is seen as the only alternative and then rejected, as it is wrongly correlated to homoeroticism. The perceived need for self-expression invites for a movement toward the false cure of femininity, and this movement is cyclically followed by a movement away from femininity. Always approaching, but never getting there, and never realizing the fallacy that is the movement itself and the narrow concepts involved, masculinity remains unchanged.

While these matters remain open throughout most of King's novels, the representation of femininity shifts as the decades pass. The rejected feminine characterizes King's initial novels, but several works King published in the 1990s operate under a different premise. In Gerald's Game, Dolores Claiborne, and Rose Madder, female characters are less cardboard and more human, displaying the complexity with which King paints his male protagonists. While the content of King's initial novels seems to corroborate the characters essentialist views of femininity, his recent novels narrate such circumstances more critically. Abusive men frequently exclude women in King's older novels, but his recent stories show exclusion coming from female characters instead. This is not, moreover, simply a mirrored copy of an already inaccurate representation, since women do not reject men to reassert femininity, but to avoid unhealthy male traditions.

From Gerald's Game on, King's female characters seem less passive in relation to abuse, often overreacting with complete distrust for men. As Magistrale writes, "In Gerald's 
65. MAGISTRALE. Stephen King: America's Storyteller, p. 86.

66. KING. Doctor Sleep, p. 25.
Game and Dolores Claiborne, all of King's female protagonists grow so disillusioned by abusive male sexuality that they retreat into asexual, exclusively female relationships" ${ }^{65}$ In this initial stage, the portrayal changes from victimhood to rejection of masculinity, which, without questioning the correlation between abuse and masculinity, changes the status quo of women while maintaining their simplistic portrayal. Even in novels published later, like Doctor Sleep, King presents such characters. Andrea Steiner, for example, "didn't like men" because of the abusive actions of her father, who "had raped her for the first time when she was eight" ${ }^{66}$ She is the stereotype of the lesbian who rejects maleness, attributing it to the crime of her father. In this full reversal of his passive female characters, King alters the words, but does not correct the premises behind the discourse. His shortsighted female characters remain attached to traditional and outdated gender stereotypes. Sustaining the gap between the masculine and the feminine, some women tend to see men as utterly destructive, while the recurrence of perpetually flawed male characters ensure those women are right.

Despite the constant presence of these characters, their significance tends to decrease in King's works produced after the 1990s. While Andrea Steiner (Doctor Sleep) reverses the reaction but not the stereotypes, other character are complex enough to recognize plurality in masculinities. When Rose leaves home in Rose Madder, she is also leaving behind the archetype of the abused woman, not merely reversing the way it is represented. She finds the company of women in a home for victims of abuse and, while they actively reject abusive men, they welcome the help of emotionally healthy people independently of gender. In an event hosted by the women of Daughters and Sisters, the home for abused women of which Rose is part, "there were enough men that Norman did not feel particularly conspicuous" ${ }^{67}$ After blending in and asking a woman if he was interfering with the event, Norman hears that he should "Stay. Hang out. Enjoy" ${ }^{68}$ Additionally, Gert, a friend of Rose, is one of the few traditionally masculine women found in King's fiction. She is "an extremely large woman, one who actually did bear a slight resemblance to William 'Refrigerator' Perry", ${ }^{69}$ a heavily built retired football player. Her size, her strength, and her fighting abilities, despite giving her an emblematic masculine quality, are never a problem for Daughters and Sisters. Rose's personality is also indicative of healthier gender relations, since she is shaped by the abuse she suffered, as her rage demonstrates, but her depiction, as well as that of other women in Rose Madder, surpasses the stereotypical limitations shared by other female characters who are victims of abuse. While King tends to represent abused women as either fragile or
67. KING. Rose Madder, p. 325.

68. KING. Rose Madder, p. 326.

69. KING Rose Madder, p. 326. 
70. MAGISTRALE. Stephen King: America's Storyteller, p. 140 irrationally aggressive, Rose carries the marks of her traumatic experiences, but refuses any oversimplified response to her trauma.

Male characters, however, do not undergo the same adjustment. Norman, for instance, begins and ends Rose Madder as a one-sided monstrous figure. Magistrale identifies a general problem in King's representation of men in his novels that focus on women, noting,

The men in King's feminist fictions are severely drawn, as caricatured as the women characters for which he was so justly criticized in his earliest writings. They are vicious, one-dimensional miscrea nts that sacrifice everything - families, marriages, children, and their own sanities-in their will to dominate and, even more objectionably, sexually violate daughters and wives. $^{70}$

The complexity of one gender, then, comes at the expense of the other, who is transformed into a foil whose lack of dimension only serves to highlight the complexity of the main characters.

Doctor Sleep is a partial exception. Unlike The Shining, Pet Sematary, and Rose Madder, it features two protagonist of different genders who are not in diametric opposition. While secondary characters (e.g., Andrea Steiner) carry certain stereotypes, Dan Torrance and Abra Stone have a healthy relationship. There is neither a failed sexual aspect to their relationship nor a dynamic of domination or passivity. The key difference, though, is that Dan and Abra's relationship is not romantic, but one of uncle/niece or mentor/apprentice. They do not so much break a pattern as they circumvent it. Not every male/female relationship is problematic in King's fiction, but, when they involve prospects of romance or the influence of marriage, they often include men and women who either clash violently or live happily ever after in love. The abusive marriages I have been discussing exemplify the first, while flawless and saccharine couples such as Rose McClendon and Bill Steiner in Rose Madder, or Frances Goldsmith and Stuart Redman in The Stand exemplify the second. Realistic romantic relationships, with both enjoyment and strife, happen mostly in secondary couples, such as the Stones (Doctor Sleep) or the Coslaws (Cycle of the Werewolf). Frequently, when a romantic relationship has any relevant bearing on the plot, it works under these stereotypical patterns, being either abusive or too perfect. Perhaps this indicates that these opposed stereotypes are tied to the representation of marriage, sex, and romance, and not to any relationship between men and women. Nevertheless, what Magistrale observes about sexuality in King's fiction remains true: adult, heterosexual 
romantic relationships can never just be, always, instead, existing to fulfill a function.

Even though female victims of abuse in King's stories tend to carry more traumas, they address them more openly and are more successful in their process of healing. Jack Torrance, Dick Halloran, and Norman Daniels were abused by older men, either physically or sexually, but they tend to ignore their tra umas. It is women like Rose who can address their past experiences. In addition, when thinking of masculinity in King's novels, it is easier to correla te it to abusers, not victims. When Rose escapes her abusive marriage, she successfully solves a personal instance of a social problem, which can be handled more easily by fiction writers, since escaping from abuse is an adequate start for solutions in relation to the victim. Since in King's stories the abusers are predominantly male, approaching the problem through the lenses of masculinity means that escaping is neither a personal nor a social solution, since adjustment on the behavior of abusers requires meticulous processes, not an escape. To provide any mea ningful healing to the wound of masculinity, King's novels would have to delve into the assumptions behind it, which implies both a return to the open matters of morality, evil, and free-will and a revaluation of the portrayal of social and romantic
BELO HORIZONTE
N. 3 relationships involving men and women. This is a much harder task, which King has approached only tangentially.

\section{CONCLUSION}

In his novels, King provides a number of possible strategies for healing the wounds of masculinity, but, while they seem promising at first, they ultimately bring no significant change. Personal injuries, such as unhealthy relationships with alcohol or sexuality, may be corrected, but the sta te of affairs persists. Their characters are doomed to irreversible predicaments, and gender, which is given innate proprieties, functions as a cage. Works such as It, "The Body", "Rita Hayworth and the Shawshank Redemption", and "Mister Yummy", reaffirm the open nature of the masculine wound, revealing problems in the interpersonal relations between King's characters. Sociability and sexuality, which is frequently tied to morality, reveal how traditional masculine identity is often established at the expense of others, excluding and restricting whoever is different. The wound of masculinity, unable to close, causes perpetual pain to men and women alike.

While the depiction of women characters has arguably improved throughout King's fiction, male characters tend to live as representations of problems of masculinity. The complexity of one gender comes at the expense of the other. 
Multifaceted women are either pursued by masculine embodiments of anger or married to passive and tasteless men, while complex men abuse overly simplified women.

The problems that King portrays are impossible to solve in the fictional worlds he builds. From King's stories, we get that traditional, conservative men are in crisis because of sexually-deviant (usually gay) men and nagging women. The gay men are portrayed as predators; the women, as emasculating. If one takes those stereotypes in consideration, it becomes clear that King's masculinities are there fo rhetorical purposes, ensuring the conserva tiveness of traditional values at the expense of non-traditional groups. They adhere to dated "truths" with little hesitation or skepticism.

King's depiction of masculinity is partly a flaw and partly a representation of real problems. Some of his descriptions of traditional and toxic manhood are laudable achievements. Jack Torrance's self-fulfilling fears and Louis Creed's negotiation with responsibility are good examples. Nevertheless, none of these depictions suggest significant ways to handle issues of masculinity, since this is a much harder task. Even if we generalize and forget about the sensitive nature of gender relations, the most basic question King's novels would have to answer in order to suggest a closing of the manhood wound is, "What is it that makes a person stop acting immorally and acting morally?" This inquiry seems too vast even for a writer whose published novels now span decades.

The most inconvenient part of studying masculinities in King's fiction is not the recognition of masculinity as an open wound. The trouble is that, even after all my observations, it remains hard to imagine masculinity being shown as anything else. I do not mention this with the intention of rethinking or rewriting King's novels, and not even as an exercise in imagination. This is an observation about popular horror culture and the difficulty of understanding manhood as something positive while inserted in such culture. Seeing masculinity in a favorable way is not an easy task.

\section{REFERENCES}

ALEGRE, Sara Martín. "Nightmares of Childhood: The Child and the Monster in Four Novels by Stephen King". Atlantis, n.p., v. 23, n. 1, p. 105-114, 2001

\section{BEAL, Kimberly. "Sometimes Being a Bitch is All a}

Woman Has": Stephen King, Gothic Stereotypes, and the Representation of Women. Thesis (MA), Ohio U, Athens, 2012

BEYNON, John. Masculinities and Culture. Philadelphia: Open $U$ P, 2002. 
BIDDLE, Arthur. "The Mythic Journey in 'The Body'". In

MAGISTRALE, Tony. Dark Descent. Westport: Greenwood Press, 1992. p. 83-97.

BRUHM, Steven. "Picture This: Stephen King's Queer Gothic".

n: PUNTER, David. A New Companion to the Gothic. Hoboken: Blackwell, 2012. p. 469-81.

CARROLL, Brett. American Masculinities: A Historical

Encyclopedia. Thousand Oaks: SAGE, 2003.

DYMOND, Erica. "From the Present to the Past: An Exploration of Family Dynamics in Stephen King's Pet Sematary". The Journal of Popular Culture, n.p.: v. 46, n. 4, p. 789-810, 2013.

ELLER, Jackie. "Wendy Torrance, One of King's Women: A Typology of King's Female Characters". In: Magistrale, Tony. The Shining Reader. Mercer Island, Starmont House, 1990. p. 11-22.

GUTHRIE, James Ronald. Three Decades of Horror: Domestic Violence, Patriarchy, and the Evolution of Female Characters in Stephen King's Fiction. Thesis (MA), U of Alabama, 2009

HOBBS, Alex. "Masculinity Studies and Literature". Literature Compass, n.p.: v. 10, n. 4, p. 383-95, 2013.

HOHNE, Karen. "The Power of the Spoken Word in the Works of Stephen King." The Journal of Popular Culture, n.p., v. 28, n. 2, p. 93-103, 1994.

KING, Stephen. "1408". In: KING, Stephen. Everything's

Eventual New York: Pocket Books, 2007. p. 365-404.
"Apt Pupil". In: KING, Stephen. Different Seasons. New York: Signet, 1995. p. 107-286.

Bag of Bones. New York: Pocket Books, 1999

Blaze. New York: Scribner, 2007.

Carrie. New York: Doubleday, 1974

Cycle of the Werewolf. New York: Signet, 1985

Danse Macabre. London: Hodder \& Stoughton, 2006

Dark Tower series. 1982-2012

Doctor Sleep. New York: Pocket Books, 2013

Dolores Claiborne. London: Hodder \& Stoughton, 1993.

Duma Key. New York: Scribner, 2008.

Gerald's Game. New York: Gallery Books, 2016.

"Herman Wouk Is Still Alive". In: KING, Stephen. The Bazaar of Bad Dreams. New York: Scribner, 2015. Kindle.

It. New York: Simon and Schuster, 2016

Lisey's Story. New York: Scribner, 2006.

Misery. New York: Viking, 1987 
. "Mister Yummy". In: KING, Stephen. The Bazaar of Bad Dreams. New York: Scribner, 2015. Kindle.

"Morality". In: KING, Stephen. The Bazaar of Bad Dreams. New York: Scribner, 2015. Kindle.

Mr. Mercedes. New York: Scribner, 2014

Pet Sematary. London: Hodder \& Stoughton, 2010

"Premium Harmony". In: KING, Stephen. The Bazaar of Bad Dreams. New York: Scribner, 2015. Kindle.

"Rainy Season". In: KING, Stephen. Nightmares \& Dreamscapes. New York: Simon and Schuster, 2009. p. 453-479.

Revival. New York: Scribner, 2015.

"Rita Hayworth and the Shawshank Redemption". In KING Stephen. Different Seasons. New York: Signet, 1995. p. 13-106.

Rose Madder. New York: Signet, 1996

"The Body". In: KING, Stephen. Different Seasons. New York: Signet, 1995. p. 287-433.

The Dead Zone. New York: Simon and Schuster, 2016.

The Green Mile. London: Gollancz, 2010

The Shining. New York: Anchor, 2013
The Stand: Complete and Uncut Edition. New York: Anchor, 1990.

Thinner. London: Hodder \& Stoughton, 2007.

"Ur". In: KING, Stephen. The Bazaar of Bad Dreams New York: Scribner, 2015. Kindle.

"You Know They Got a Hell of a Band". In: KING, Stephen. Nightmares \& Dreamscapes. New York: Simon and Schuster, 2009. p. $367-418$

MAGISTRALE, Tony. Stephen King: America's Storyteller Westport: Praeger, 2010

NAPIER, Will. The Haunted House of Memory in Stephen King's Fiction. Thesis (PhD), U of Glasgow, 2008.

NILSEN, Sarah. "White Soul: The 'Magical Negro' in the Films of Stephen King". In: MAGISTRALE, Tony. The Films of Stephen King: From Carrie to Secret Window. New York, Palgrave MacMillan, 2008. p. 129-140

PARKS, Tim. "The Pleasures of Reading Stephen King", The New York Review of Books, New York, vol LXIII, n. 15, October 2016 , p. 26-27.

PUNTER, David. The Literature of Terror: A History of Gothic Fictions from 1765 to the Present Day. London: Longman, 1980

SEDGWICK, Eve Kosofsky. Between Men: English Literature and Male Homosocial Desire. New York: Columbia UP 1985. 
SENF, Carole. "Gerald's Game and Dolores Claiborne: Stephen

King and the Evolution of an Authentic Female Narrative Voice".

Imagining the Worst. Westport: Greenwood, 1998. p. 91-110.

STRENGELL, Heidi. "The Ghost: The Gothic Melodrama in

Stephen King's Fiction." European Journal of American Culture n.p.: vol. 24, n³ 3 2005, p. 221-38

SULLIVAN, Kate. "Stephen King's Bookish Boys: (Re)lmagining

the Masculine". Michigan Feminist Studies, Ann Arbor, v. 14,

1999-2000, n.p. Available at: <https://quod.lib.umich.edu/cgi/t/

text/text-idx? $\mathrm{cc}=\mathrm{mfsfront} ; \mathrm{c}=\mathrm{mfs} ; \mathrm{c}=\mathrm{mfsfront} ; \mathrm{idno}=\operatorname{ark5583.001}$

$4.002 ; \mathrm{g}=\mathrm{mfsg} ; \mathrm{rgn}=$ main;view $=$ text; $x \mathrm{c}=1>$. Accessed on: Apr.

6,2018

Submetido: $11 / 04 / 2018$

Aceito: $23 / 04 / 2018$ 